\title{
Obscenity or Taboo? Remarks on Profanities in Juvenal and Martial
}

\author{
Gergő Gellérfi \\ (University of Szeged)
}

\begin{abstract}
When examining obscene expressions and taboos in the Latin language, one cannot rely on the modern concepts of profanities or taboos at all, since the limits of obscenity were drawn much further than in our times, as it is sufficiently demonstrated by certain elements of the Roman culture. It is enough to mention the custom of hanging a phallic charm on babies' necks, or the fascini used to ward the evil away from conquering generals. In my paper, I deal with the appearance of themes and expressions that can be considered as obscene in the poems of Martial and Juvenal. In doing this, I have examined the graffiti-corpus found in the cities destroyed by the eruption of Mount Vesuvius in 79 AD, being the most important contemporary source of these expressions. The analysis of these literary texts can bring us closer to revealing where the aforementioned limits were drawn in the Latin language of the $1^{\text {st }}$ and $2^{\text {nd }}$ century AD.
\end{abstract}

\section{Keywords}

Juvenal; Martial; obscenity; profane language

The research has been developed with the support of MTA-SZTE Antiquity and Renaissance: Sources and Reception Research Group (TK2016-126) and the János Bolyai Research Scholarship of the Hungarian Academy of Sciences. 
Obscene expressions in Greek and Latin literature have caused many problems for translators and editors, which has lead to different solutions in order to avoid the use of the so-called "offensive language". ${ }^{1}$ For instance, the renowned Hungarian translator, Gábor Devecseri left certain poems out from his translation of Catullus; ${ }^{2}$ while in other poems, he used euphemisms instead of expressions that seemed unacceptable. For example, the predicate of glubit magnanimos Remi nepotes $(58,5)$ is velöt fej, i.e. "she milks bone marrow" in Hungarian, while the translation of pedicabo ego vos ac irrumabo $(16,1)$ is majd alul-fölül érzitek, i.e. "you will feel it down there and up there" in his edition. Of course, translators should not be blamed for this method, since they had to adjust to the circumstances of their age; however, this kind of "refinement", so to speak, of the language of ancient literature, changing a literary work's characteristics, can be observed today as well.

Besides the omission and alteration of these expressions in translation, there is another strategy to avoid the use of obscene words: that is the translation of Greek and Latin words or poems into the other language. Some editions, for example certain volumes of the Loeb Classical Library, translate the Greek poems with obscene content into Latin or the Latin poems into Italian instead of English, ${ }^{3}$ and a similar method is applied by the Oxford Latin Dictionary and the Greek-English Lexicon of Liddell, Scott and Jones. In the latter case, this practice can cause problems for the users of the dictionaries, since sometimes they explain a Greek and a Latin word with each other; for example, in the case of the Latin landica and the Greek escharadin - both meaning "clitoris".

Turning back to the topic of literary texts translated with the use of euphemisms or with the technique of omitting certain parts of the texts: whatever reason motivates these changes, they create a bigger distance between the original text and its translation than inevitable. An obscene expression ${ }^{4}$ is an organic part of a text, and therefore its omission takes something away from it. For instance, if someone translates both of Martial's and Juvenal's poems in this "euphemistic way", the translated texts will not show the important differences between the two poets regarding their word usage while describing obscene topics that will be demonstrated later in my paper. And moreover, when dealing with ancient texts written in extinct languages, we cannot rely on the modern concepts of profanities or taboos at all, since the limits of obscenity were not equal to those of our time. This is sufficiently demonstrated by certain elements of the Roman

1 I am grateful to the reviewers for their comments on the first draft of this paper, especially for the remark on the possible motivations of the Pompeiian inscriptions; this question is really intriguing, however, I am convinced that it deserves separate examination, since the word-usage of these inscriptions can be analysed without dealing with this issue.

2 Devecseri (1958). He omits the poems 27, 56, 59, 80 and 97 from this edition, while in his first edition, he left out certain lines containing profane content.

3 For example, Ker (1919).

4 Concerning the concept of "obscenity", I followed the definition of Henderson (1991: p. 2): "By 'obscenity' we mean verbal reference to areas of human activity or parts of the human body that are protected by certain taboos agreed upon by prevailing social custom and subject to emotional aversion or inhibition. These are in fact the sexual and excremental areas. In order to be obscene, such a reference must be made by an explicit expression that is itself subject to the same inhibitions as the thing it describes." 
culture: it is enough to mention the phallus-shaped fascini that were worn by babies around their necks or as a ring on their fingers, fulfilling a warding-off function - and of course, there are plenty of other examples of the depictions of male genitalia, sometimes with legs and wings. These amulets, lamps, reliefs, and mosaics can be regarded as extremely obscene from the modern viewpoint, which makes it clear for us how carefully should the concepts of profanities and taboos be dealt with.

Having said that, nothing compels us to doubt that the concept of "obscene expression" existed in the classical Roman age. The primary evidences of this are two texts of Cicero who explains the postpositional use of the preposition cum in the expression nobiscum ("with us") in his Orator, stating that if we say cum nobis, "the letters would run together in a rather obscene way" - since it is easy to mistake it for cunno bis. ${ }^{5}$ In the $22^{\text {nd }}$ epistle of Book 9 of his Epistulae Familiares, he deals with the same topic, highlighting some expressions that must be avoided since they can be understood as rude words. For example, he warns us never to use the diminutive of the word pavimentum ("floor") because it would contain the word mentula, being the obscene word for the male genitalia. ${ }^{6}$

Martial also reflects on the use of rude words but in the opposite way: he does not reject them but on the contrary, he actually incorporates their use in his poetic programme. It can be observed in Epigram 69 of his Book 3, where he renders the epigrams of Cosconius with nulla mentula as suitable only for children and virgins, while his own poetry using these words freely is convenient for adult and older readers. ${ }^{7}$ In Epigram 15 of his Book 11, he writes that "our book should not talk by circumscription about the thing from which we originate and the begetter of everyone that was named mentula by the sacred Numa". ${ }^{8}$ With these words, he does not simply give an ars poetical statement on his word usage, but also invokes an honourable figure of the mythical-historical past, as an authority, in order to "legitimize" his use of obscene expressions. The latter argument, however, is not necessarily valid, since the obscene status of a word can change with time. ${ }^{9}$ If we look at the possible etymologies of the word mentula that can be derived from mens ("mind"), ${ }^{10}$ from menta ("mint"), from a hypothetical verb *mentare, or explained as a cognate of eminere ("to stand out, to project"), mentum ("chin") and mons

5 Cic. Or. 154: ... cum autem nobis non dicitur, sed nobiscum? Quia si ita diceretur, obscaenius concurrerent litterae...

6 Cic. Fam. 9, 22, 3: belle 'tectoriola'. dic ergo etiam 'pavimenta' isto modo: non potes.

7 Mart. 3, 69: omnia quod scribis castis epigrammata verbis / inque tuis nulla est mentula carminibus, / admiror, laudo; nihil est te sanctius uno: / at mea luxuria pagina nulla vacat. / haec igitur nequam iuvenes facilesque puellae, / haec senior, sed quem torquet amica, legat. / at tua, Cosconi, venerandaque sanctaque verba / a pueris debent virginibusque legi.

8 Mart. 11, 15, 8-10: nec per circuitus loquatur illam, / ex qua nascimur, omnium parentem, / quam sanctus Numa mentulam vocabat.

9 This can be observed in modern languages as well, to which I present an example from my native language: according to the etymological dictionary of Zaicz (2006: p. 59), the verb "baszik", the most common Hungarian profane word for the sexual intercourse that is undoubtedly obscene nowadays, originally served as a euphemistic substitute for a contemporary obscene word after having been borrowed from a Turkish language.

10 Mentioned by Adams (1982: p. 10) and Valpy (1828: p. 538) among others. 
("mountain"), ${ }^{11}$ we can conclude that it is plausible that the word was not always an obscene one - for example, if the derivation from mens is the correct one, then we can suppose that an earlier non-obscene, humorous word with the meaning of "little mind" was transferred to the field of the obscenities, losing its humorous component.

The possible change of the obscene status of certain words is only one of the problems making the examination of Latin profanities and their usage more complicated. In this paper, I do not aim to examine the question in its complexity, but to present a case study on the limits of obscenity and taboo in the Roman literature, focusing on two authors of the Silver Age: Martial and Juvenal. Besides due to including a variety of sexuality-related topics, I chose these two poets, being almost contemporaries, writing in different genres, because their word usage can be compared with an almost contemporary non-literary text corpus. This is the graffiti-corpus preserved on the walls of the buildings of Pompeii and Herculaneum, giving us some insight into the vulgar language of the time a few decades before the two poets' writing period. The corpus that was published in the fourth volume of Corpus Inscriptionum Latinarum provides us information on the currency, the usage, the obscene status, and the exact meaning of certain words.

Now I will briefly present this graffiti-corpus, focusing on those aspects that are important for my paper. The thousands of graffiti preserved in the destroyed cities show a wide thematic variety. Among others, we can find promotions of gladiatorial fights, inscriptions of victories and lines referring to the escape of gladiators, greetings, remembrances, love messages, poems of great Roman poets, and their imitations, as well as shape poetry. Besides these, there are also a lot of advertisements in the corpus, of course; for example, the one that was found on the outer wall of a shop: "A bronze pot has been taken from this shop. Whoever brings it back will receive 65 sesterces. If he produces the thief, from whom we may take our property back, will receive 84 sesterces". ${ }^{12}$

There are also plenty of sexual advertisements in the corpus, mentioning the type of service, its price and the name of the prostitute, not only in brothels but also in the vicinity of inns and other public places. The language of these graffiti is quite moderate sometimes; for example, the following inscription was found next to the basilica of Pompeii: "I am yours for two coins". ${ }^{13}$ However, others are much more plain-spoken; for example, the advertisements of Glyco and Euplia offering oral sex for two and five coins. ${ }^{14}$ Two other pieces of graffiti also mention the name of the latter prostitute who, according to one of them, was "[t]here" with two thousand good-looking men, while the

11 The other etymologies (besides the possible derivation from mens) are summarized by Messing (1956: pp. 247-249), who dismisses menta and eminere, as well as the supposed relation with the Sanskrit word mánthati. However, his explanation of mentula as a joke-word from *mentare, which was not current before Catullus, seems unconvincing to me.

12 CIL IV 64: urna aenia pereit de taberna seiquis rettulerit dabuntur H-S LXV sei furem dabit unde [rem] servare po[ssimus H-S] XX C IIII; the text is quoted according to Wallace (2005: p. 31).

13 CIL IV 5372: sum tua ae(ris) a(ssibus) II; the text is quoted according to Weeber (1996: p. 67).

14 CIL IV 3999: Glyco cunnum lingit a(ssibus) II; 5048: Euplia f(ellat) a(ssibus) V; the texts are quoted according to Weeber (1996: p. 67) and DiBiasie (2015: p. 191). 
other one refers explicitly to the fact that her genitalia are overused. ${ }^{15}$ The ancient walls also preserved positive and negative ratings of prostitutes; for instance, the performance of Myrtis is praised, but the oral sex given by Sabina is criticized. ${ }^{16}$ A peculiar "rating", so to say, was written on a wall in the form of a distich, commemorating a nice and popular but, according to the inscriptor, "muddy" girl. ${ }^{17}$

Among the sexuality-related graffiti of the destroyed cities, one can find a lot of similar inscriptions remembering a sexual intercourse, which are much closer in style to the modern graffiti than the aforementioned advertisements. These inscriptions often contain the verb futuo that occurs rarely in literary texts, appearing almost only in the language of epigram, as will be demonstrated later. Just to mention a few examples: one graffito states that Ampliatus Afer got laid in that place together with his friends; another inscriptor had sex twice at the location of his inscription; a third one was with the barmaid at an inn, whereas Messius had no luck. ${ }^{18}$ And moreover, a similar inscription alludes to the Caesarean veni, vidi, vici, stating that hic ego cum veni, futui, deinde redei domi ${ }^{19}$ Besides the use of this verb, the graffiti-corpus includes expressions denoting sexuality-related and digestive body functions, homosexual intercourse, ${ }^{20}$ and according to Varone's interpretation, one inscription even refers to an act of striptease. ${ }^{21}$ This line could be continued with the occurrences of different parts of the genitalia and several bodily functions.

As will be demonstrated later, most of the aforementioned obscene words appearing in the graffiti-corpus of the destroyed cities occur in the epigrams of Martial as well. The usage of obscene words of his contemporary fellow poet, Juvenal, however, is quite the opposite: although never dealing explicitly with the question of rude words, Juvenal follows similar principles as Cicero when avoiding even the use of any basic obscenities like mentula, cunnus, futuo, etc. He does that, in spite of the fact that various sexual activities appear in his Satires to illustrate the crimes and faults of the contemporary Rome, and in particular promiscuity and adultery. This is, above all, true for Satires 2 and 9, dealing with homosexuality and effemination, and for Satire 6, presenting intercourse with animals, masturbation and a women's orgy among others. It is also worth noting that the generic tradition of the satire would allow him to use some expressions that can be

15 CIL IV 2310b: Euplia hic cum hominibus bellis $m$ m; 10004: Eupl[i]a laxa landicosa; the texts are quoted according to Wallace (2005: p. 74) and DiBiasie (2015: p. 191).

16 CIL IV 2273: Myrtis bene felas; 4185: Sabina fellas, non belle fac $(i)$ s; the texts are quoted according to Weeber (1996: pp. 71, 48).

17 CIL IV 1516: hic ego nu(nc f)utue formosa fo( $(r)$ ma puella $(\mathrm{m})$, / laudata $(\mathrm{m})$ a multis, set lutus intus eerat; the text is quoted according to Weeber (1996: p. 47).

18 CIL IV 3942: Ampliatus Afer hic futuit cum suis sodalibus; 4029: hic ego bis futui; 8442: futui coponam; 5187: Messius hic nihil futuit; the texts are quoted according to Weeber (1996: p. 46).

19 CIL IV 2246; the text is quoted according to Weeber (1996: p. 72).

20 CIL IV 8879b: eiacula puber; 10619: Apollinaris medicus Titi imp hic cacavit bene; 2319b: Vesbinus cinedus, Vitalio pedicavit; the texts are quoted according to Weeber (1996: p. 55), McKeown (2010: p. 186) and Weeber (1996: p. 57).

21 CIL IV 3951: Restutus (dicit): Restetuta, pone tunica, rogo, redes pilosa co(nnum); see Varone (2002: p. 98). 
regarded as obscene, since in the poems of a prominent satiric predecessor, Horace, the verbs futuo and caco as well as the noun cunnus do appear. ${ }^{22}$

Instead of obscene expressions, Juvenal uses euphemisms, metaphors and circumscriptions. ${ }^{23}$ An example of the latter can be observed in a line of Satire 1, where the infinitive cacare is substituted by non tantum meiiere $(1,131)$. In his sexuality-related passages, Juvenal's metaphors and euphemisms are mostly moderate. The verb futuo, the basic obscenity for sexual intercourse, is substituted by inclino ("to bend"), resupino ("to turn on back") and palpito ("to tremble") among others, and the verb admitto that is typically used to describe the breeding of animals in the meaning of "sending to" also appears in a similar context. ${ }^{24}$ The male genitalia is denoted by words inguen ("groin"), nervus ("nerve", "sinew", "tendon") and cicer ("chickpea") among others. ${ }^{25}$ But, no matter how cautious his word usage is, Juvenal also takes the liberty of using some bolder substitutions; for example, in Satires 1 and 6 instead of cunnus, he uses vesica, a medical term for the bladder, ${ }^{26}$ while in Satire 9 the verb fodio ("to dig") appears simultaneously in its literal meaning and metaphorically referring to the anal intercourse: "That slave is less miserable who digs the field than who digs his lord". ${ }^{27}$

As the aforementioned examples sufficiently demonstrate, no act or body part is taboo for Juvenal, but he does not use any basic obscenities. However, the latter statement still needs further proving, since there are some expressions in the Satires that can possibly be regarded as obscene ones: these are the verbs criso, ceveo and lambo, the nouns penis and podex, and the adjective verpus. ${ }^{28}$ The latter one is a derivative of verpa that is never referred to as an obscene word, but on the base of its occurrences Adams classifies it as "an emotive and highly offensive word". ${ }^{29}$ The adjective verpus with the meaning of "circumcised" seems to be an offensive reference to Jewish people, but nothing suggests handling the word as an obscene one. The noun podex has very limited occurrences, and

22 Hor. S. 1, 2, 127: dum futuo; 1, 8, 38: in me veniat mictum atque cacatum; 1, 3, 107-108: nam fuit ante Helenam cunnus taeterrima belli / causa.

23 These characteristics of Juvenal's style gave place to some misunderstandings and over-interpretations, as in the case of the commentary of Nadeau (2011: pp. 181-182) on Satire 6, stating that in lines 309 and 310 , the urinating on the statue of Pudicitia (micturiunt hic / effigiemque deae longis siphonibus implent) refers to female ejaculation, without any further explanation. His interpretation is criticised by Watson (2012).

24 E.g. Juv. 9, 25-26: notior Aufidio moechus celebrare solebas, / quodque taces, ipsos etiam inclinare maritos; 3, 112: horum si nihil est, aviam resupinat amici; 3, 133-134: ... donat Calvinae vel Catienae, / ut semel aut iterum super illam palpitet.

25 E.g. Juv. 1, 41: partes quisque suas ad mensuram inguinis heres; 9, 34: nil faciet longi mensura incognita nervi; 6 , 373b: follisque pudet cicerisque relicti.

26 Juv. 1, 38-39: ... in caelum quos evehit optima summi / nunc via processus, vetulae vesica beatae; 6, 64: ... Tuccia vesicae non imperat...

27 Juv. 9, 45-46: ... servus erit minus ille miser qui foderit agrum / quam dominum.

28 Juv. 6, 322: ... ipsa Medullinae fluctum crisantis adorat; 2, 21: ego te ceventem, Sexte, verebor?; 9, 40: computat et cevet; 2, 49: Tedia non lambit Cluviam nec Flora Catullam; 6, 336-338: sed omnes / noverunt Mauri atque Indi quae psaltria penem / maiorem quam sunt duo Caesaris Anticatones...; 2, 11-13: hispida membra quidem et durae per bracchia saetae / promittunt atrocem animum, sed podice levi / caeduntur tumidae medico ridente mariscae; 14, 104: quaesitum ad fontem solos deducere verpos.

Adams (1982: pp. 12-14). 
therefore it is hard to classify it; anyway, it is used by medical writers of Late Antiquity as an anatomical term. ${ }^{30}$ The noun penis can be offensive in certain contexts (cf. Cic. Fam. $9,22,2)$, but it is clearly not as obscene as mentula, since Cicero cites it openly, while mentula is mentioned only by circumscription. Besides Satire 6, where it seems to be a pure anatomical term, the word also occurs in Satire 9: agere intra viscera penem (9, 43). This expression is quite gross, but since it stands for the obscene word pedicare, we can classify these words as an "anatomical circumscription". On the grounds of its occurrences in literary texts, we can state with confidence that the verb lambo is not obscene, since it gets sexual connotation only by the context, in contrast to the verb lingo, the other verb that can denote the act of cunnilingus, which has strong sexual connotation. ${ }^{31}$ Concerning the verbs criso and ceveo, we can also rely on their appearances in the texts of certain authors: criso is used even by Donatus, while in the case of ceveo, the occurrences in Persius and Juvenal are the strongest evidences that this verb is not obscene, since otherwise it would be the only obscene word in the texts of both of the two authors. ${ }^{32}$

Thus, we can rightly say that Juvenal always substitutes obscene words with circumscriptions, metaphors, euphemisms, or anatomical terms. Turning to the other examined text-corpus, Martial's epigrams, the word mentula, which can be regarded as clearly obscene on the base of Cicero's aforementioned letter and a passage in the Priapeia collection, appears most frequently in Martial's texts among the surviving Roman literature; and the same can be said about the word cunnus, the basic obscenity for the female genitalia - and both of these expressions occur frequently in the graffiti-corpus of the destroyed cities as well. Having said that, Martial sometimes also refers to these body parts metaphorically; for example, naming the mentula as columna $(6,49,3)$ or inguinis arma $(6,73,6)$, or the cunnus as pudicitia $(10,63,8$ - next to the word mentula!), but it is far more typical of him to use expressions that can be regarded as obscene without doubt on the basis of other literary and epigraphical evidence.

Just as in the case of the nouns mentula and cunnus, the verb futuo occurs in Martial's epigrams much more frequently than in any other text of the surviving Roman literature: the verb excluding its derivatives appears twice in Catullus, once in Horace, twice in the Priapeia collection, and three times in an epigram attributed to Octavian, while Martial uses it 49 times. It is a common verb in the graffiti-corpus as well, appearing on more than 60 inscriptions - according to Adams, its frequency is due to the fact that this verb was a technical term, so to speak, used for the unemotional sexual relations between prostitutes and clients. ${ }^{33}$

Regarding other obscene expressions in Martial's writings, the nouns culus, fellator, fututor and fututrix, as well as the verbs pedico, irrumo, fello and lingo all occur multiple times in the epigrams, just like in the graffiti-corpus from Pompeii and Herculaneum while Juvenal never uses any of them. But there is one word that is never used even by

30 Adams (1982: p. 112) does not consider it as "gross" as Courtney (1980: pp. 45-46).

31 Cf. Adams (1982: pp. 135-136).

32 A possible explanation is that the verbs denoting sexual movements of the passive partner (criso, ceveo) are not as offensive as the words describing an active role (futuo, pedico), cf. Adams (1982: p. 137).

33 Adams (1982: pp. 120-121). 
Martial. This is the noun landica denoting the clitoris appearing only once in the whole surviving Roman literature, in the $78^{\text {th }}$ poem of the Priapeia collection. The word occurs only twice in inscriptions, one of which is a Pompeiian graffito using its derivative adjective landicosa..$^{34}$ The much less frequent occurrence of the word compared to that of the others cannot refute that it was well-known and widespread, since words like culus and irrumo appear on the inscriptions of the destroyed cities only five and six times respectively (compared to the dozens of occurrences of other obscenities), but hardly can it be questioned whether they were well-known at the time.

While never using the word landica, three different classical Latin authors refer to the clitoris unambiguously. In one of his epigrams, Martial mentions a woman called Saufeia who may be ashamed of the size of her clitoris, ${ }^{35}$ while in another poem he refers to the idea that this part of the female genitalia can be used as a penis in a sexual relation between two women. ${ }^{36}$ The idea of the connection between the penis and the clitoris also appears in a poem of Phaedrus, who explains the existence of the tribades as follows: Prometheus ... errore ebrio ... masculina membra applicuit feminis $(4,16)$, i.e. he refers to an unusually large clitoris as a "male part" attached to a female body by mistake. Juvenal uses the word crista ("crest") instead of landica ${ }^{37}$ that is absolutely not unusual of him, since he replaces obscene words with euphemisms and metaphors. However, the fact that Martial, who speaks openly about practically every other parts, functions and activities of the human body, also avoids using the word landica while referring to the organ, means that this is not only a "simple" obscene word, but as I see it, the word and the clitoris itself can be considered as a taboo. Apart from the medical literature,${ }^{38}$ these five passages and two inscriptions are the only mentions of or references to the landica, which also strengthens its taboo status. But the word itself must have been well-known in my opinion, which is certified by Cicero's aforementioned epistle on the avoidance of expressions that can be understood as obscene. He mentions a sentence in which the word landica could be heard: hanc culpam maiorem an illam dicam? If we look at the other obscene expressions being referred to in this section of his letter, which are futuo, penis, cunnus, the Greek verb $\beta \iota v \varepsilon ́ \omega$, and mentula, we can see that all of them are words that can be rightly considered as well-known obscenities. I cannot see why he would include a quite unknown word with an unclear meaning in this list.

According to my hypothesis, we can explain the taboo status of the clitoris with the aforementioned texts of Martial and Phaedrus. The idea that this part of the female body can be used for penetration, and the concept that clitoris is (or at least, can be)

34 CIL IV 10004: Eupl[i]a laxa landicosa; CIL XI 6721: peto landicam Fulviae.

35 Mart. 3, 72, 6: ... aut aliquid cunni prominet ore tui.

36 Mart. 1, 90, 7-8: inter se geminos audes committere cunnos / mentiturque virum prodigiosa Venus; cf. Howell (1980: ad loc.); Adams (1982: p. 98); Hallett (1989: pp. 215-217); for an opposing view, see Boehringer (2007: pp. 321-324).

37 Juv. 6, 422: callidus et cristae digitos inpressit aliptes.

38 The word's appearance in the medical literature can be sufficiently explained by the fact that the landica was the verbum proprium to denote the clitoris, and it did not have a non-obscene counterpart like the penis and the mentula. 
a male part renders the landica as incongruous with the standard male-female dichotomy, as well as with the, so to speak, traditional sexual roles of the two genders. The assumption of the ancient concept of the connection between the penis and the clitoris is also strengthened by the possible etymology of the word landica that is explained by Fay as the diminutive of glans. ${ }^{39}$ Thus, as opposed to "simple" obscenities like mentula, cunnus etc., the "little glans" on the female body that can be used for penetration in certain cases, became a taboo.

This hypothesis and similar questions need further investigation, since the analysis of expressions that can be regarded as obscene ones will have further results concerning the so-called "rude words" in classical Latin language, as well as in connection with the contemporary thinking of sexuality. Moreover, it can also help translators to find the most proper modern language word as the counterpart of a sexuality-related Latin or Greek expression.

\section{Bibliography}

Adams, J. N. (1982). The Latin Sexual Vocabulary. London: Duckworth.

Boehringer, S. (2007). L'homosexualité féminine dans l'Antiquité grecque et romaine. Paris: Les Belles Lettres.

Courtney, E. (1980). A Commentary on the Satires of Juvenal. London: Athlone Press.

Devecseri, G. (Transl.). (1958). Catullus költeményei. Budapest: Európa Könyvkiadó.

DiBiasie, J. F. (2015). The Writings on the Wall: the Spatial and Literary Context of Domestic Graffiti from Pompeii. Dissertation Austin.

Fay, E. W. (1907). Greek and Latin word studies. The Classical Quarterly, 1, 13-30.

Hallett, J. P. (1989). Female Homoeroticism and the Denial of Roman Reality in Latin Literature. Yale Journal of Criticizm, 3, 209-227.

Henderson, J. (1991). The Maculate Muse: Obscene Language in Attic Comedy. New York - Oxford: Oxford University Press.

Howell, P. (1980). A Commentary on Book One of the Epigrams of Martial. London: Athlone Press.

Ker, W. C. A. (Transl.). (1919). Martial: Epigrams. London - New York: Heinemann - Putnam.

McKeown, J. C. (2010). A Cabinet of Roman Curiosities. Oxford: University Press.

Messing, G. M. (1956). The Etymology of Lat. Mentula. Classical Philology, 51, 247-249.

Nadeau, Y. (2011). A commentary on the Sixth Satire of Juvenal. Bruxelles: Éditions Latomus.

Valpy, F. E. J. (1828). An Etymological Dictionary of the Latin Language. London: Baldwin and Co.

Varone, A. (2002). Erotica Pompeiana: Love Inscriptions on the Walls of Pompeii. Rome: L'Erma di Bretschneider.

Wallace, R. E. (2005). An Introduction to Wall Inscriptions From Pompeii and Herculaneum. Wauconda: Bolchazy-Carducci.

39 Fay (1907: pp. 13-14). 
Watson, L. C. (2012). Yvan Nadeau: A Commentary on the Sixth Satire of Juvenal (Rev.). Bryn Mawr Classical Review, 2012.09.19 (retrieved 30.10.2017 from http://bmcr.brynmawr.edu/2012/201209-19.html).

Weeber, K.-W. (1996). Decius war hier... Das Beste aus der römischen Graffiti-Szene. Zürich - Düsseldorf: Artemis \& Winkler.

Zaicz, G. (Ed.). (2006). Etimológiai szótár: Magyar szavak és toldalékok eredete. Budapest: Tinta Könyvkiadó.

Dr. Gergő Gellérfi / gellerfigergo@gmail.com

Department of Classical Philology and Neo-Latin Studies

University of Szeged, Faculty of Arts

Egyetem u. 2, 6722 Szeged, Hungary 